\title{
Increased serum levels of chromogranin A in male smokers with airway obstruction
}

\author{
S. Sørhaug*,\#, A. Langhammer", H.L. Waldum ${ }^{+, \S}$, K. Hveem ${ }^{\star}$ and S. Steinshamn*,\#
}

ABSTRACT: The neuroendocrine (NE) system may play an important role in smoking-induced airway diseases. The aim of the present study was to examine the relationship between serum levels of the general NE marker chromogranin $\mathrm{A}(\mathrm{CgA})$ and smoking habits, respiratory symptoms and lung function.

The study population consisted of never-smokers with normal lung function, smokers with normal lung function and smokers with airway obstruction who were randomly selected from the lung study of the Nord-Trøndelag Health Study (HUNT). Serum CgA was determined in 151, 138 and 116 subjects, respectively. All subjects were seronegative for Helicobacter pylori.

Male smokers with airway obstruction had significantly higher serum CgA levels (median 3.70 $\mathrm{nmol} \cdot \mathrm{L}^{-1}$ (interquartile range 3.10-5.15)) than both smokers with normal lung function (3.00 $\left.\mathrm{nmol} \cdot \mathrm{L}^{-1}(2.50-3.67)\right)$ and never-smokers with normal lung function $\left(2.90 \mathrm{nmol} \cdot \mathrm{L}^{-1}(2.57-3.30)\right.$ ). The elevated levels of $\mathrm{CgA}$ correlated with the degree of airway obstruction. Moreover, the presence of respiratory symptoms and chronic bronchitis among male smokers were associated with increased serum $\mathrm{CgA}$ levels. Females had $\mathrm{CgA}$ levels similar to male smokers independent of smoking status and lung function.

Elevated serum chromogranin A levels in subjects with airway obstruction and respiratory symptoms may represent neuroendocrine activation in inflammatory or remodelling processes in the lung.

KEYWORDS: Airway obstruction, chromogranin A, lung function, neuroendocrine system, sex, smoking

$\mathrm{t}$ has been proposed that a subgroup of airway epithelial cells, known as pulmonary neuroendocrine cells (PNEC) may play an important role in the pathogenesis of smokinginduced airway diseases [1]. These cells, which belong to the diffuse neuroendocrine (NE) system, are distributed in the airways among other epithelial cells either as single cells or as aggregates (neuroepithelial bodies; NEB), which are thought to be specialised innervated chemoreceptors that sense the alveolar oxygen level [2]. The function of the pulmonary NE system is not completely known, but may be important in control of growth and development of the foetal lung. In addition, it may contribute to regulation of ventilation and circulation in the post-natal and adult lung [3]. These NE cells may also play a role in the carcinogenesis of lung cancer, as their secretory products can serve as tumour growth factors and may be the cellular origin of lung tumours with NE features [3,4].

Previous studies have shown a possible relationship between cigarette smoking and changes in the pulmonary NE system. In conditions such as chronic obstructive pulmonary disease (COPD) and emphysema, cigarette smoking has been associated with increased numbers of PNEC and NEB $[5,6]$. In addition, some animal models have shown hyperplasia of PNEC/NEB and increased expression of NE peptides after exposure to cigarette smoke or its components $[7,8]$. Many of the peptides or bioactive amines secreted from the PNEC may play a role in the inflammatory processes of airway diseases as growth factors, immunoregulators or neurotransmitters [9]. NEB have also been proposed as a link between the inflammatory reaction in the airways and the induction of hyperreactivity through the release of mediators that lead to an increase in excitability and activity of nerve fibres [10].

Chromogranin A $(\mathrm{CgA})$ is a glycoprotein that belongs to the family of secretory proteins found in dense core vesicles of all NE cells. Exposed to appropriate stimulating factors, $\mathrm{CgA}$ is coreleased with other peptide hormones or bioactive amines from the secretory granules of $\mathrm{NE}$ cells. This makes $\mathrm{CgA}$ a good serum marker of
AFFILIATIONS

Depts of *Circulation and Medical Imaging, and,

${ }^{+}$Cancer Research and Molecular Medicine, Faculty of Medicine,

Norwegian University of Science and Technology, and,

Depts of \# Pulmonary Medicine, and, ${ }^{\S}$ Medicine, Section of Gastroenterology, St. Olavs Hospital, Trondheim, and

-HUNT Research Centre, Norwegian University of Science and

Technology, Verdal, Norway.

CORRESPONDENCE

S. Sørhaug

Dept of Pulmonary Medicine

St. Olavs Hospital

N-7006 Trondheim

Norway

Fax: 4773867424

E-mail: sveinung.sorhaug@ntnu.no

Received:

August 092005

Accepted after revision:

April 222006

SUPPORT STATEMENT

This study was supported by SINTEF Health Research and the Cancer Foundation of St. Olavs Hospital (both Trondheim, Norway). The Bronchial Obstruction in NordTrøndelag (BONT) study was funded by AstraZeneca, Norway. NordTrøndelag Health Study (the HUNT Study) is a collaboration between the HUNT Research Centre, Faculty of Medicine, Norwegian University of Science and Technology (NTNU, Verdal), the Norwegian Institute of Public Health, and the NordTrøndelag County Council, Norway.

European Respiratory Journa Print ISSN 0903-1936 Online ISSN 1399-3003 
NE activity [11]. In addition to the effects of NE secretory proteins, co-secreted $\mathrm{CgA}$ may have a proposed influence on smoking-induced airway diseases [12]. To the present authors' knowledge, no studies examining the general NE marker CgA in cigarette-smoking subjects have been published. Therefore, the present authors decided to study the relationship between serum levels of $\mathrm{CgA}$ and smoking status, lung function and respiratory symptoms in a cross-sectional study.

\section{MATERIALS AND METHODS}

\section{Subjects}

During 1995-1997, a health survey (the Nord-Trøndelag Health Study or the HUNT Study) was conducted in the Norwegian county of Nord-Trøndelag. It included 65,225 participants, representing $71 \%$ of all subjects aged $\geqslant 20 \mathrm{yrs}$. The participants answered questionnaires on health, diseases, symptoms and risk factors. Venous blood samples were taken from all subjects. A substudy, the Bronchial Obstruction in NordTrøndelag (BONT) study, invited a random 5\% sample of the total study population $(n=2,791)$ and, in addition, those reporting asthma or asthma-related symptoms $(n=8,150)$ to undergo flow/volume spirometry and a structured interview [13]. Three main categories from the BONT study were randomly selected for further serological analysis: 1) neversmokers with normal lung function $(n=1,649) ; 2)$ ever-smokers (including both current smokers and ex-smokers (ceased smoking $\geqslant 1$ yr earlier)) with normal lung function $(n=879)$; and 3) ever-smokers with obstructive spirometric values $(n=359)$. All smokers should have a history of $>10$ pack-yrs of smoking. Among these groups, 223, 276 and 354 subjects, respectively, were randomly selected for assessment of Helicobacter pylori (HP) status, and only serum of HP-negative subjects (151, 138 and 116, respectively) were further analysed for $\mathrm{CgA}$ (fig. 1). The selection of HP-negative subjects was carried out to reduce a possible gastric contribution to increased CgA levels, as a previous study has shown a relationship between infection with $\mathrm{HP}$ and hyperplasia of $\mathrm{NE}$ cells in the gastric mucosa with increased levels of circulating CgA [14]. A total of $23 \mathrm{HP}$-negative subjects were excluded from the study because of missing variables, misclassification or high serum creatinine that could interfere with the serum levels of $\mathrm{CgA}$ (creatinine $>140 \mu \mathrm{mol} \cdot \mathrm{L}^{-1}$ in males and $>120 \mu \mathrm{mol} \cdot \mathrm{L}^{-1}$ in females). The study was approved by the Regional Committee for Ethics in Medical Research and the Norwegian Data Inspectorate.

\section{Spirometric measurement and definitions}

The flow/volume spirometry was recorded by trained staff using three pneumotachographs (MasterScope spirometer; Erich Jaeger GmbH, Würzburg, Germany) according to the recommendations of the American Thoracic Society [15]. The predicted forced expiratory volume in one second (FEV1) was calculated using prediction equations estimated for this population [16]. FEV1 $\geqslant 80 \%$ of predicted value and FEV1/ forced vital capacity (FVC) $>0.70$ was defined as normal lung function according to the definition by the Global Initiative for Chronic Obstructive Lung Disease (GOLD) [17]. FEV1<80\% pred and FEV1/FVC $<0.70$ was defined as an obstructive spirometry. Subjects with $\mathrm{FEV} 1 / \mathrm{FVC}<0.70$ were further classified according to the GOLD classification as mild/ moderate COPD, those with $\mathrm{FEV} 1 \geqslant 50 \%$ (grades I-II), and those with $\mathrm{FEV} 1<50 \%$ (grades III-IV) as severe/very severe COPD.

Chronic bronchitis was defined as reported cough with phlegm for at least 3 months during the 2 yrs leading up to the study. The number of pack-yrs was calculated as years of smoking multiplied by number of cigarettes smoked per day divided by 20 .

\section{Analyses of blood samples}

Venous blood samples were collected between 08:00 $\mathrm{h}$ and 19:00 h, and were stored at $-70^{\circ} \mathrm{C}$ until analysis. Immunoglobulin (Ig)G antibody to HP in serum was measured using the commercial enzyme immunoassay Pyloriset EIA-IgG (Orion Diagnostica, Espoo, Finland) at Levanger Hospital, The Nord-Trøndelag Hospital Trust, and titre values $>300$ were scored as positive. CgA were analysed at the Dept of Laboratory Medicine (St. Olavs Hospital, Trondheim, Norway) using a commercial radioimmunoassay method with reagents from EuroDiagnostica, Malmø, Sweden. This method is based on polyclonal antibodies raised in rabbits against the amino acid sequence $116-439$ of the CgA molecule, and has been shown to detect both intact $\mathrm{CgA}$ and fragments of $\mathrm{CgA}$ [18]. The intra- and interassay coefficient of variation with this method was $<10 \%$.

\section{Statistical analysis}

Continuous, normally distributed variables are given as mean $\pm \mathrm{SD}$, whilst measures of $\mathrm{CgA}$ due to non-normal distribution are reported as median (interquartile range). All analyses were stratified by sex. Unpaired t-tests and MannWhitney U-test were used for comparisons between groups of normally and non-normally distributed values, respectively. Between-groups differences for $\mathrm{CgA}$ were tested with ANOVA with Bonferroni's post hoc test after log transformation. Categorical data were tested by the Chi-squared test. The impact of the predictor variables age, pack-yrs, FEV1 \% pred, presence of respiratory symptoms and serum creatinine on $\log -\mathrm{CgA}$ was tested using linear regression models stratified by sex. Sex differences were tested in corresponding models without stratification, including sex and the interaction terms $\left(\mathrm{FEV}_{1} \%\right.$ pred $\times$ sex) and (pack-yrs $\times$ sex). A two-tailed $\mathrm{p}$-value $<0.05$ was considered statistically significant.

\section{RESULTS}

\section{Characteristics of the study population}

There were large differences in sex distribution between the three study groups, with female dominance among neversmokers with normal lung function and an opposite pattern in obstructive smokers (fig. 1). Furthermore, there were major differences in HP status between the three main categories selected from BONT, with $68 \% \mathrm{HP}$-negative in never-smokers, $50 \%$ in smokers with normal lung function and $33 \%$ in obstructive smokers.

In total, 180 males and 202 females fulfilled the criteria for further analyses of $\mathrm{CgA}$ (table 1). Among these, the prevalence of never-smokers was higher in females and the mean smoking burden (pack-yrs) was higher in males. No significant difference by sex was seen regarding respiratory symptoms. 


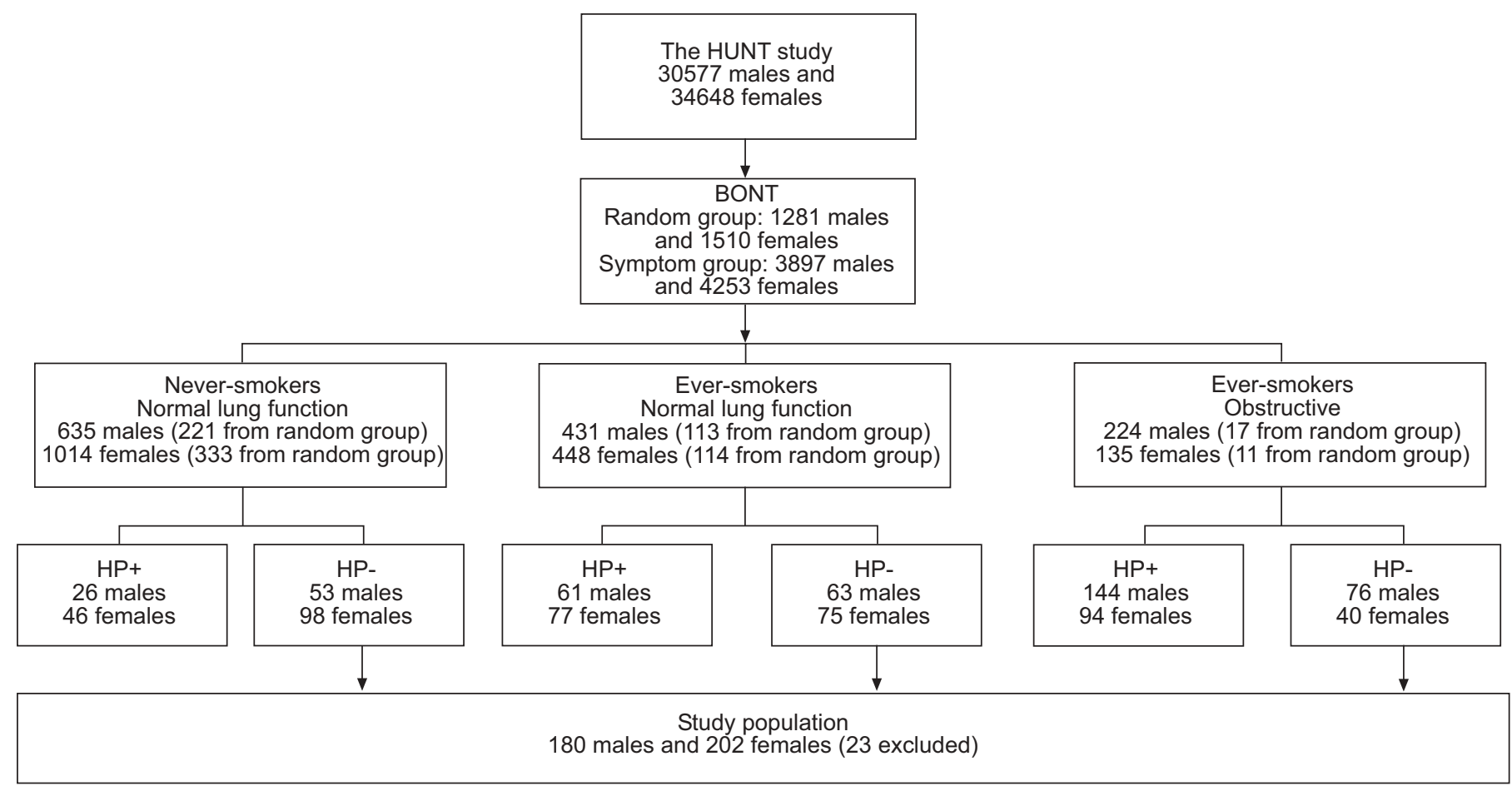

FIGURE 1. Selection procedure for inclusion of study subjects from the Nord-Trøndelag Health Study (HUNT Study) and the substudy Bronchial Obstruction in NordTrøndelag (BONT), which included a 5\% randomised group (random group) from HUNT and a group with self-reported respiratory symptoms (symptom group). HP +/seropositive/seronegative status of Helicobacter pylori

\section{CgA and smoking history}

Serum levels of CgA did not differ significantly between males and females when the entire study population was compared (median $3.20 \mathrm{nmol} \cdot \mathrm{L}^{-1}$ (interquartile range $2.60-4.00$ ) versus $\left.3.30 \mathrm{nmol} \cdot \mathrm{L}^{-1}(2.70-4.00), \mathrm{p}=0.660\right)$. However, stratification by smoking history revealed a different pattern between the sexes

\begin{tabular}{|c|c|c|c|c|}
\hline TABLE 1 & \multicolumn{4}{|c|}{$\begin{array}{l}\text { Characteristics of the study population stratified } \\
\text { for sex }\end{array}$} \\
\hline \multicolumn{2}{|c|}{ Characteristics } & Male & Female & p-value \\
\hline \multicolumn{2}{|l|}{ Subjects } & 180 & 202 & \\
\hline \multicolumn{2}{|l|}{ Age yrs } & $53.5 \pm 11.8$ & $52.9 \pm 11.6$ & 0.579 \\
\hline \multicolumn{5}{|c|}{ Smoking history } \\
\hline \multicolumn{2}{|c|}{ Never-smokers } & 25.6 & 43.6 & $<0.001$ \\
\hline \multicolumn{2}{|c|}{ Ex-smokers } & 16.1 & 9.9 & 0.002 \\
\hline \multicolumn{2}{|c|}{ Current-smokers } & 58.3 & 46.5 & 0.001 \\
\hline \multicolumn{2}{|c|}{ Pack-yrs (ever-smokers) } & $29.0 \pm 11.3$ & $19.3 \pm 7.4$ & $<0.001$ \\
\hline \multicolumn{5}{|c|}{ Respiratory symptoms } \\
\hline \multicolumn{2}{|c|}{ Wheezing or breathlessness } & 57.8 & 55.9 & 0.681 \\
\hline \multicolumn{2}{|c|}{ Daily coughing } & 45.0 & 42.6 & 0.633 \\
\hline \multicolumn{2}{|c|}{ Chronic bronchitis } & 17.8 & 11.9 & 0.104 \\
\hline \multicolumn{5}{|c|}{ FEV $1 \%$ pred } \\
\hline \multicolumn{2}{|c|}{ Never-smokers } & $100.6 \pm 10.4$ & $99.8 \pm 11.9$ & 0.699 \\
\hline \multicolumn{2}{|c|}{ Ever-smokers } & $71.9 \pm 24.5$ & $79.2 \pm 20.5$ & 0.012 \\
\hline
\end{tabular}

Data are presented as $\mathrm{n}$, mean $\pm \mathrm{SD}$ and $\%$ of each sex. FEV 1 : forced expiratory volume in one second; \% pred: \% predicted. (fig. 2). CgA levels in females were independent of smoking history, whilst male never-smokers had a lower serum level of $\mathrm{CgA}$ (2.90 nmol $\left.\cdot \mathrm{L}^{-1}(2.57-3.30)\right)$ compared with currentsmokers $\left(3.40 \mathrm{nmol} \cdot \mathrm{L}^{-1}(2.80-4.20), \mathrm{p}=0.046\right)$. Interestingly, males from the latter group had a similar level of $\mathrm{CgA}$ to female never-smokers $\left(3.30 \mathrm{nmol} \cdot \mathrm{L}^{-1}(2.65-4.10)\right)$.

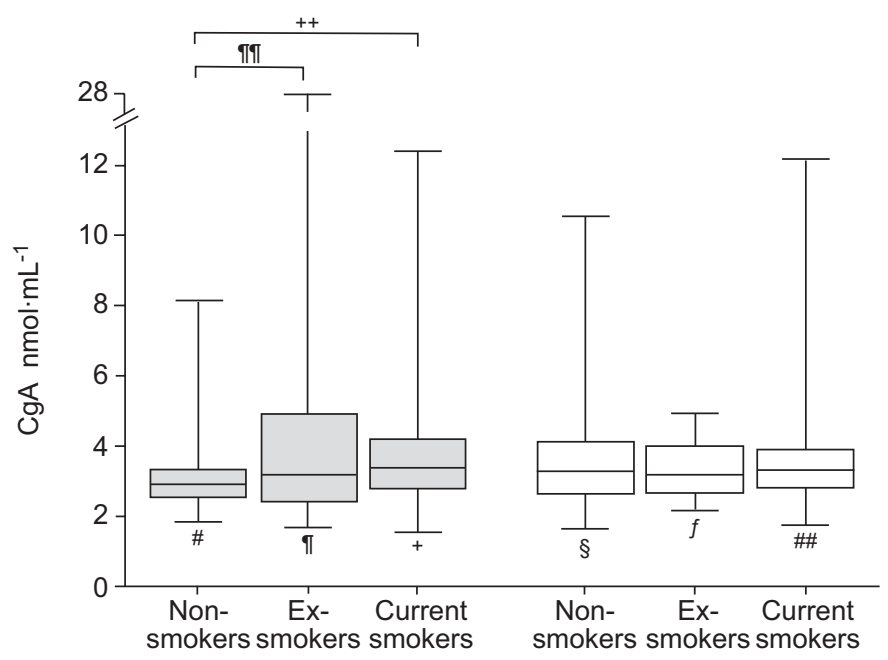

FIGURE 2. Sex-specific serum levels of chromogranin $A(\mathrm{Cg} A)$ in nonsmokers compared with ex-smokers and current smokers. Data are presented as boxes showing median (interquartile range) values, and whiskers with minimum and maximum values. $\square$ : males; $\square$ : females. ${ }^{*}: n=46 ;{ }^{n}: n=29 ;{ }^{+}: n=105 ;{ }^{\varsigma}: n=88 ;$ : $n=20 ;{ }^{\# \#}: n=94 ;{ }^{\oplus}: p=0.022 ;{ }^{++}: p=0.046$. 


\section{$\mathrm{CgA}$ and lung function}

Male smokers with airway obstruction had higher serum $\mathrm{CgA}$ levels $\left(3.70 \mathrm{nmol} \cdot \mathrm{L}^{-1}(3.10-5.15)\right)$ than both smokers with normal lung function $\left(3.00 \mathrm{nmol} \cdot \mathrm{L}^{-1}(2.50-3.67), \mathrm{p}<0.001\right)$ and never-smokers with normal lung function $\left(2.90 \mathrm{nmol} \cdot \mathrm{L}^{-1}(2.57-\right.$ 3.30), $\mathrm{p}<0.001$; fig. 3). Male subjects with severe/very severe COPD (GOLD classification) had significantly higher serum levels of $\mathrm{CgA}\left(4.40 \mathrm{nmol} \cdot \mathrm{L}^{-1}(3.10-5.70)\right)$ compared with participants with both normal lung function $\left(3.00 \mathrm{nmol} \cdot \mathrm{L}^{-1}\right.$ (2.50-3.52), $\mathrm{p}<0.001)$ and mild/moderate COPD $\left(3.60 \mathrm{nmol} \cdot \mathrm{L}^{-1}\right.$ (3.00-4.50), $\mathrm{p}=0.042$; fig. 4). In females, moderately, but not statistically significant, higher levels of serum $\mathrm{CgA}$ were found in the most severe COPD group compared with the normal lung function group $\left(3.80 \mathrm{nmol} \cdot \mathrm{L}^{-1}(3.00-4.30)\right.$ versus 3.15 $\left.\mathrm{nmol} \cdot \mathrm{L}^{-1}(2.70-3.90), \mathrm{p}=0.899\right)$.

\section{CgA and respiratory symptoms}

Serum levels of $\mathrm{CgA}$ related to respiratory symptoms and smoking status are summarised in table 2. Male smokers with respiratory symptoms such as daily cough and episodes of wheezing or breathlessness during the last year had significantly higher levels of serum CgA compared with asymptomatic subjects. Among never-smokers, only females with respiratory symptoms had significantly higher levels of $\mathrm{CgA}$ compared with participants without these symptoms. Both male and female smokers with self-reported symptoms of chronic bronchitis had higher levels of serum CgA than asymptomatic subjects, but the difference was only statistically significant in males.

\section{Multiple linear regression analysis}

In males, age (regression coefficient 0.0033 (95\% confidence interval (CI) 0.0009-0.0056), $\mathrm{p}=0.007)$, lung function $(-0.0016$

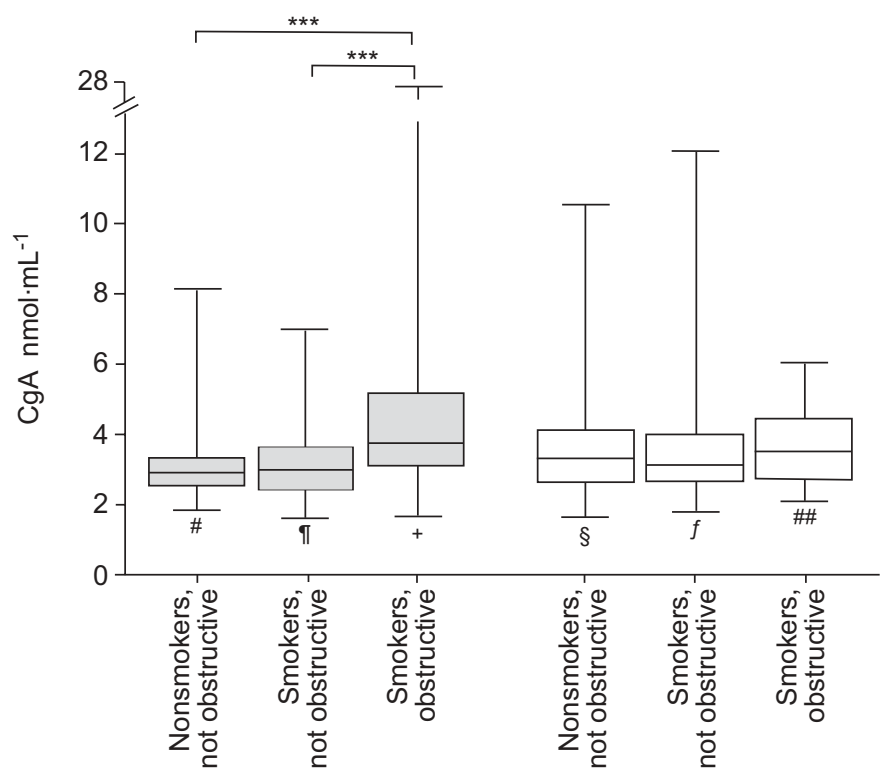

FIGURE 3. Serum levels of chromogranin A (CgA) in nonsmokers with normal lung function, compared with smokers with normal lung function and smokers with airway obstruction, stratified by sex. Data are presented as boxes showing median (interquartile range) values, and whiskers with minimum and maximum values. males; $\square$ : females. ${ }^{\#}: n=46 ;{ }^{\bullet}: n=64 ;{ }^{+}: n=70 ;{ }^{\S}: n=88 ;{ }^{f}: n=74 ;{ }^{\# \#}: n=40 . * * *$ : $\mathrm{p}<0.001$
$(95 \% \mathrm{CI}-0.0028--0.0003), \mathrm{p}=0.013)$ and serum creatinine $(0.0027$ (95\% (CI) 0.0008-0.0046), $\mathrm{p}=0.006)$ were independent predictors for $\mathrm{CgA}$ levels using multiple linear regression analysis, together accounting for $25 \%$ of the variability of CgA. Packyrs and presence of respiratory symptoms (daily cough and episodes of wheezing or breathlessness) were not significant predictors. In females, age (0.0030 (95\% CI 0.0014-0.0046), $\mathrm{p}<0.001)$ and presence of respiratory symptoms $(0.0422(95 \%$ CI $0.0009-0.0835), p=0.045$ ) were identified as independent predictors of circulating $\mathrm{CgA}$, but accounted for only $10 \%$ of the overall variability of $\mathrm{CgA}$. A test of interaction of sex on the association between smoking burden and $\mathrm{CgA}$, and lung function and $\mathrm{CgA}$ by the interaction terms (FEV1\% pred $\times$ sex) and (pack-yrs $\times$ sex) in a nonstratified model, revealed that neither interaction terms $(0.0014$ (95\% CI -0.0012-0.0039) and -0.0009 (95\% CI $-0.0025-0.0006)$, respectively) were significant predictors for $\mathrm{CgA}$.

\section{DISCUSSION}

The main finding of the current study was that there are higher levels of serum CgA in male smokers with impaired lung function than in smokers with normal lung function and in never-smokers. In addition, respiratory symptoms were associated with elevated $\mathrm{CgA}$ levels in male smokers. These differences were not significant in females.

$\mathrm{CgA}$ is a protein that belongs to a family of secretory peptides found in NE cells [12]. It is co-released exocytotically with many different NE hormones and is regarded as a good marker of increased general NE activity, as elevated levels in blood are linked to NE activation and hyperplasia or neoplasia of $\mathrm{NE}$ tissues. In clinical use, $\mathrm{CgA}$ is considered a diagnostic marker of NE tumours and there is a strong correlation between the level of $\mathrm{CgA}$ and the NE tumour mass [19, 20].

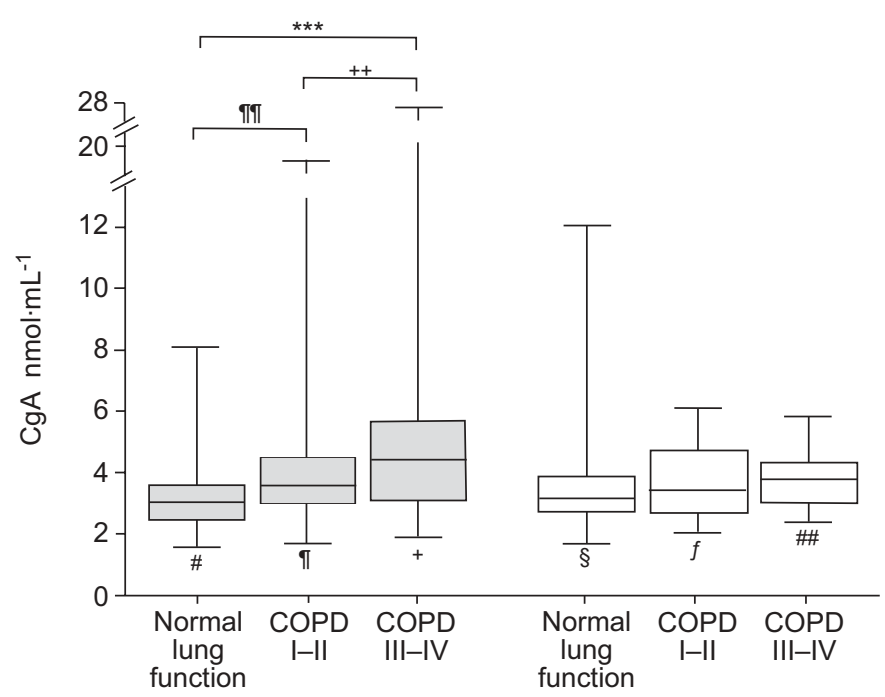

FIGURE 4. Sex-specific serum levels of chromogranin $A(\mathrm{CgA})$ in subjects with normal lung function compared with subjects with airway obstruction according to their stage classified by the Global Initiative for Chronic Obstructive Lung Disease. Data are presented as boxes showing median (interquartile range) values, and whiskers with minimum and maximum values. COPD: chronic obstructive lung disease grades I to IV. $\square$ : males; $\square$ : females. ${ }^{\#}: n=110 ;{ }^{\top}: n=43 ;{ }^{+}: n=27 ;{ }^{\S}$ : $n=162 ;{ }^{f}: n=29 ;{ }^{\# \#}: n=11 ;{ }^{\text {ฯ }}: p=0.009 ;{ }^{++}: p=0.042 ; * \star *: p<0.001$. 


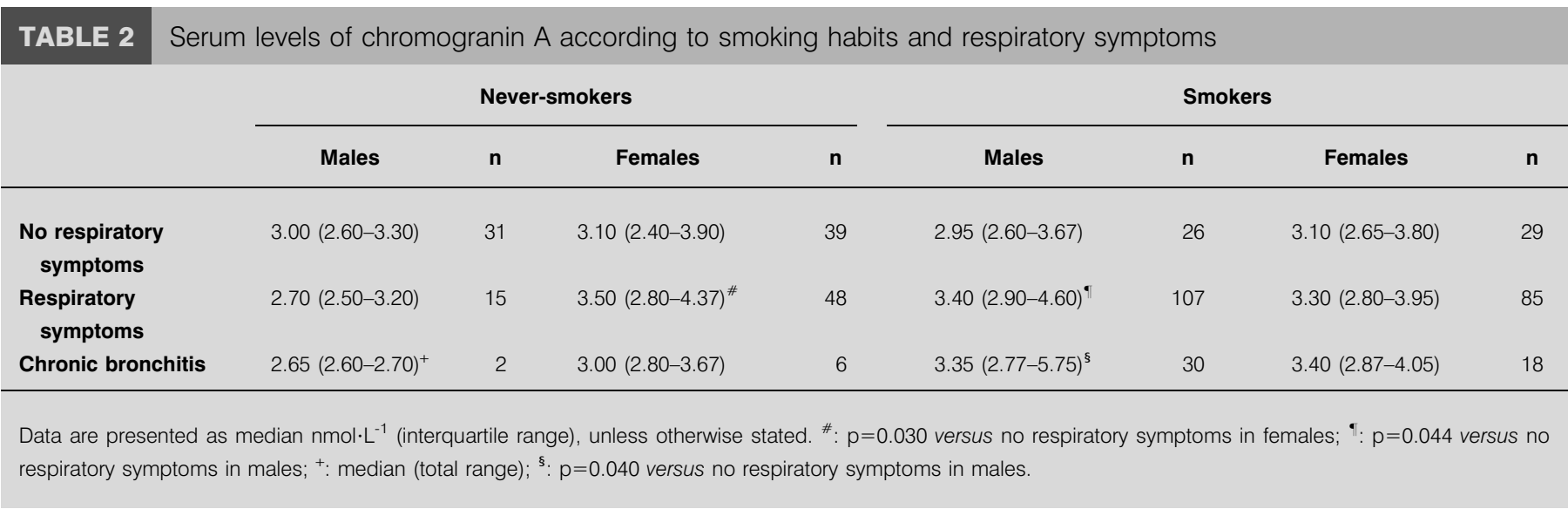

Some important functions of CgA inside the NE cells include regulation of granulogenesis and hormone storage. In addition, recent studies have shown that $\mathrm{CgA}$ can function as a prohormone, giving rise to bioactive split-products that may exert modulating effects in an autocrine, paracrine or endocrine manner.

Some CgA-derived peptides have potential roles in the pathophysiology of smoking-induced lung disorders. Vasostatin I and II are CgA fragments that bind to smooth muscle cells of the resistance vessels and inhibit vasoconstriction $[21,22]$. Thus, they may have a regulatory role in vascular complications of respiratory diseases or smoking-related cardiovascular damages. In addition, vasostatin I seems to promote fibroblast adhesion, suggesting a role in the remodelling process of respiratory diseases [23]. Another fragment, named catestatin, exerts a negative feedback control on catecholamine release from the adrenal medulla, which is important in the control of sympathetic activity [24]. Furthermore, some fragments also show bacteriolytic and antifungal effects, making CgA and its split-products potential components of the immunological response to respiratory diseases and infections [25]. Considering these potential properties, $\mathrm{CgA}$ may have a role in inflammatory lung diseases or COPD, in addition to the co-secreted products from PNEC/NEB.

The origin of elevated $\mathrm{CgA}$ levels observed in this study may be local secretion from the NE cells within the lungs due to inflammatory or remodelling processes. In patients with inflammatory diseases associated with cigarette smoking, such as COPD and emphysema, histopathological studies have shown hyperplasia of PNEC and NEB [5, 6]. Moreover, increased levels of NE hormones, such as bombesin-like peptides, are found in human bronchioalveolar lavage fluid from smokers compared with nonsmokers, suggesting that the increase in pulmonary NE cells corresponds to a hyperproduction of these neuropeptides [26].

However, elevated circulating levels of CgA may reflect a general NE activation. COPD is now regarded as a systemic disease with an impact on various organs [27]. In addition, COPD is often associated with cardiovascular diseases. Both COPD and cardiovascular diseases may activate NE cells in the adrenal medulla, the pituitary glands or the lungs [28]. In a study by CECONI et al. [29], elevated levels of serum CgA were found in patients with chronic heart failure. Levels of $\mathrm{CgA}$ were correlated to the severity of the syndrome, and $\mathrm{CgA}$ was found to be an independent predictor of mortality. Another study by OMLAND et al. [30] supported these findings by reporting an association between plasma $\mathrm{CgA}$ and long-term mortality after myocardial infarction. The current data do not make it possible to conclude whether the circulating $\mathrm{CgA}$ originates from hyperplasia of NE cells of the lung or if it has other sources. However, similar to the situation in cardiovascular diseases, CgA may have a prognostic significance in COPD as the levels are correlated with the degree of lung impairment. This hypothesis deserves further investigation.

Nicotine releases contents from NE cells through binding to nicotinic cholinergic receptors. These receptors are found in different NE tissues, including the lung, where nicotine stimulates secretion of peptides and serotonin from PNEC [31]. However, a previous animal study did not demonstrate any hyperplasia of PNEC or NEB in rats exposed to inhaled nicotine for 2 yrs [32]. Furthermore, a study by MELONI et al. [33] examined the associations between other NE markers, bombesin-related peptides (BRP), smoking habits and respiratory symptoms in a population sample from Northern Italy. They found that only the presence of respiratory symptoms, and not tobacco smoking, significantly predicted high urinary levels of BRP. In the current study, multivariate analysis showed that lung function and not smoking burden was a significant predictor of serum $\mathrm{CgA}$ in males. Furthermore, among males who had a history of smoking, self-reported respiratory symptoms and chronic bronchitis were associated with elevated serum CgA. The same trend was seen among females but did not reach statistical significance, possibly due to the small number of subjects. Interestingly, female neversmokers with respiratory symptoms seem to have elevated CgA levels, and the presence of respiratory symptoms was an independent predictor for $\mathrm{CgA}$ levels in females. Among male never-smokers, few reported these symptoms, making analyses inconclusive. Altogether, both data from other studies and interpretation of the present data support the hypothesis that increased levels of CgA observed in this study are related to lung disease and lung inflammation, and not to pharmacological or toxic effects of nicotine or cigarette smoke alone.

The current study shows a different pattern of circulating CgA levels in males and females with respect to lung function and 
smoking habits. However, the median levels between the sexes did not differ significantly when the entire study population was compared. Previous studies reporting serum levels of $\mathrm{CgA}$ according to sex have been conflicting. A study by TAKIYYUDDIN et al. [34] found similar basal CgA levels in both sexes. In contrast, TsAO et al. [35] described higher serum CgA concentrations in males than in females, regardless of age. NoBELs et al. [36] reported slightly higher levels of CgA in postmenopausal than in pre-menopausal females, and this was ascribed to co-secretion of gonadotrophins. Therefore, the lack of statistical difference in CgA levels between the study groups among females may be explained by an age difference, as the mean age of the female never-smokers was higher than the smokers (55 versus 49 yrs) in the current study. Furthermore, the current study showed that females with impaired lung function show a trend of increasing $\mathrm{CgA}$ related to the severity of COPD, although it did not reach statistical significance. This lack of a statistically significant difference may be explained by the small number of subjects in these groups. Further studies are needed to clarify this issue.

$\mathrm{CgA}$ is a very stable molecule in blood samples. Its immunoreactivity in plasma is not affected by repeated freezing and thawing or prolonged incubation at $37^{\circ} \mathrm{C}$ [37]. This stability makes $\mathrm{CgA}$ a reliable marker that is not vulnerable to handling of the samples. However, there have been reported significant variations in serum $\mathrm{CgA}$ during the day, with higher levels observed in the late afternoon and at night [38]. Most subjects in the current study had their blood sample taken before early afternoon, suggesting that the diurnal effects did not influence the results. However, circulating $\mathrm{CgA}$ levels may be increased by renal dysfunction. This was corrected for by excluding subjects with pathologically elevated levels. However, the multivariate analysis showed that a creatinine level within normal values was still a predictor for $\mathrm{CgA}$ in males, and may confound the results of the present study.

There are some other limitations to the present study. The selection procedure from the BONT study was randomised, but the selection according to the HP status could represent a selection bias as the percentage of excluded subjects due to positive HP status was higher in the groups with poor lung function. Furthermore, concurrent gastrointestinal disorders and medications, such as proton pump inhibitors, could interfere with the circulating $\mathrm{CgA}$ levels on the basis of hyperplasia of $\mathrm{NE}$ cells in the gastrointestinal tract $[19,39]$.

In conclusion, the current study suggests that the neuroendocrine system may play a role in smoking-induced lung diseases. Elevated serum levels of chromogranin A in male smokers with airway obstruction or respiratory symptoms may reflect neuroendocrine activation, either locally or systemically, and may represent a putative regulatory function of chromogranin A as a prohormone. The neuroendocrine activation in smokers seems to be related to smoking-induced inflammatory lung disease rather than pharmacological or toxic effects of cigarette smoke alone. Future studies should focus on the possible predictive value of chromogranin $\mathrm{A}$ as a biomarker of prognosis in smoking-associated diseases.

\section{REFERENCES}

1 Aguayo SM. Neuroendocrine cells and airway wall remodelling in chronic airflow obstruction: a perspective. Monaldi Arch Chest Dis 1994; 275: 243-248.

2 Cutz E, Jackson A. Neuroepithelial bodies as airway oxygen sensors. Respir Physiol 1999; 115: 201-214.

3 Van Lommel A. Pulmonary neuroendocrine cells (PNEC) and neuroepithelial bodies (NEB): chemoreceptors and regulators of lung development. Paediatr Respir Rev 2001; 2: 171-176.

4 Carney DN, Cuttitta F, Moody TW, Minna JD. Selective stimulation of small cell lung cancer clonal growth by bombesin and gastrin-releasing peptide. Cancer Res 1987; 47: 821-825.

5 Aguayo SM. Determinants of susceptibility to cigarette smoke. Potential roles for neuroendocrine cells and neuropeptides in airway inflammation, airway wall remodeling, and chronic airflow obstruction. Am J Respir Crit Care Med 1994; 149: 1692-1698.

6 Gosney JR, Sissons MC, Allibone RO, Blakey AF. Pulmonary endocrine cells in chronic bronchitis and emphysema. J Pathol 1989; 157: 127-133.

7 Chen MF, Diotallevi MJ, Kimizuka G, King M, Wang NS. Nicotine-induced neuroepithelial cell changes in young rabbits: a preliminary communication. Pediatr Pulmonol 1985; 1: 303-308.

8 Tabassian AR, Nylen ES, Linnoila RI, Snider RH, Cassidy MM, Becker KL. Stimulation of hamster pulmonary neuroendocrine cells and associated peptides by repeated exposure to cigarette smoke. Am Rev Respir Dis 1989; 140: 436-440.

9 Van Lommel A, Bolle T, Fannes W, Lauweryns JM. The pulmonary neuroendocrine system: the past decade. Arch Histol Cytol 1999; 62: 1-16.

10 Adriaensen D, Timmermans JP. Purinergic signalling in the lung: important in asthma and COPD? Curr Opin Pharmacol 2004; 4: 207-214.

11 Nobels FR, Kwekkeboom DJ, Bouillon R, Lamberts SW. Chromogranin A: its clinical value as marker of neuroendocrine tumours. Eur J Clin Invest 1998; 28: 431-440.

12 Taupenot L, Harper KL, O'Connor DT. The chromograninsecretogranin family. $N$ Engl J Med 2003; 348: 1134-1149.

13 Langhammer A, Johnsen R, Gulsvik A, Holmen TL, Bjermer L. Sex differences in lung vulnerability to tobacco smoking. Eur Respir J 2003; 21: 1017-1023.

14 Sanduleanu S, De Bruine A, Stridsberg M, et al. Serum chromogranin $\mathrm{A}$ as a screening test for gastric enterochromaffin-like cell hyperplasia during acid-suppressive therapy. Eur J Clin Invest 2001; 31: 802-811.

15 American Thoracic Society, Standardization of Spirometry, 1994 Update. American Thoracic Society. Am J Respir Crit Care Med 1995; 152: 1107-1136.

16 Langhammer A, Johnsen R, Gulsvik A, Holmen TL, Bjermer L. Forced spirometry reference values for Norwegian adults: the Bronchial Obstruction in NordTrondelag Study. Eur Respir J 2001; 18: 770-779.

17 National Heart, Lung and Blood Institute \& World Health Organisation. Global Initiative for Chronic Obstructive Lung Disease. 2004. www.goldcopd.com/Guidelineitem. asp? $11=2 \& 12=1 \&$ intld $=996$ Date last updated: September 2005. 
18 Stridsberg M, Oberg K, Li Q, Engstrom U, Lundqvist G. Measurements of chromogranin A, chromogranin B (secretogranin I), chromogranin C (secretogranin II) and pancreastatin in plasma and urine from patients with carcinoid tumours and endocrine pancreatic tumours. J Endocrinol 1995; 144: 49-59.

19 Syversen U, Ramstad H, Gamme K, Qvigstad G, Falkmer S, Waldum HL. Clinical significance of elevated serum chromogranin A levels. Scand J Gastroenterol 2004; 39: 969-973.

20 Hsiao RJ, Neumann HP, Parmer RJ, Barbosa JA, O'Connor DT. Chromogranin A in familial pheochromocytoma: diagnostic screening value, prediction of tumor mass, and post-resection kinetics indicating two-compartment distribution. Am J Med 1990; 88: 607-613.

21 Aardal S, Helle KB. The vasoinhibitory activity of bovine chromogranin A fragment (vasostatin) and its independence of extracellular calcium in isolated segments of human blood vessels. Regul Pept 1992; 41: 9-18.

22 Ratti S, Curnis F, Longhi R, et al. Structure-activity relationships of chromogranin $\mathrm{A}$ in cell adhesion. Identification of an adhesion site for fibroblasts and smooth muscle cells. J Biol Chem 2000; 275: 29257-29263.

23 Gasparri A, Sidoli A, Sanchez LP, et al. Chromogranin A fragments modulate cell adhesion. Identification and characterization of a pro-adhesive domain. I Biol Chem 1997; 272: 20835-20843.

24 Mahata SK, O'Connor DT, Mahata M, et al. Novel autocrine feedback control of catecholamine release. A discrete chromogranin a fragment is a noncompetitive nicotinic cholinergic antagonist. J Clin Invest 1997; 100: 1623-1633.

25 Lugardon K, Raffner R, Goumon Y, et al. Antibacterial and antifungal activities of vasostatin-1, the N-terminal fragment of chromogranin A. J Biol Chem 2000; 275: 10745-10753.

26 Aguayo SM, Kane MA, King Jr TE, Schwarz MI, Grauer L, Miller YE. Increased levels of bombesin-like peptides in the lower respiratory tract of asymptomatic cigarette smokers. J Clin Invest 1988; 43: 1105-1113.

27 Wouters EF. Chronic obstructive pulmonary disease. 5. Systemic effects of COPD. Thorax 2002; 57: 1067-1070.

28 Andreas S, Anker SD, Scanlon PD, Somers VK. Neurohumoral activation as a link to systemic manifestations of chronic lung disease. Chest 2005; 128: 3618-3624.
29 Ceconi C, Ferrari R, Bachetti T, et al. Chromogranin A in heart failure; a novel neurohumoral factor and a predictor for mortality. Eur Heart J 2002; 23: 967-974.

30 Omland T, Dickstein K, Syversen U. Association between plasma chromogranin A concentration and long-term mortality after myocardial infarction. Am J Med 2003; 114: 25-30.

31 Schuller HM, Jull BA, Sheppard BJ, Plummer HK. Interaction of tobacco-specific toxicants with the neuronal alpha(7) nicotinic acetylcholine receptor and its associated mitogenic signal transduction pathway: potential role in lung carcinogenesis and pediatric lung disorders. Eur J Pharmacol 2000; 393: 265-277.

32 Waldum HL, Nilsen OG, Nilsen T, et al. Long-term effects of inhaled nicotine. Life Sci 1994; 49: 1339-1346.

33 Meloni F, Ballabio P, Pistorio A, et al. Urinary levels of bombesin-related peptides in a population sample from northern Italy: potential role in the pathogenesis of chronic obstructive pulmonary disease. Am J Med Sci 1998; 315: 258-265.

34 Takiyyuddin MA, Neumann HP, Cervenka JH, et al. Ultradian variations of chromogranin $\mathrm{A}$ in humans. Am J Physiol 1991; 261: R939-R944.

35 Tsao KC, Wu JT. Development of an ELISA for the detection of serum chromogranin $\mathrm{A}(\mathrm{CgA})$ in prostate and non-neuroendocrine carcinomas. Clin Chim Acta 2001; 313: 21-29.

36 Nobels FR, Kwekkeboom DJ, Coopmans W, et al. A comparison between the diagnostic value of gonadotropins, alpha-subunit, and chromogranin-A and their response to thyrotropin-releasing hormone in clinically nonfunctioning, alpha-subunit-secreting, and gonadotroph pituitary adenomas. J Clin Endocrinol Metab 1993; 77: 784-789.

37 O'Connor DT, Pandlan MR, Carlton E, Cervenka JH, Hslao RJ. Rapid radioimmunoassay of circulating chromogranin A: in vitro stability, exploration of the neuroendocrine character of neoplasia, and assessment of the effects of organ failure. Clin Chem 1989; 35: 1631-1637.

38 Giampaolo B, Angelica M, Antonio S. Chromogranin " $\mathrm{A}^{\text {" }}$ in normal subjects, essential hypertensives and adrenalectomized patients. Clin Endocrinol 2002; 57: 41-50.

39 Waldum HL, Syversen U. Serum chromogranin A in the control of patients on long-term treatment with inhibitors of acid secretion. Eur J Clin Invest 2001; 31: 741-743. 